DOI: $10.20472 /$ TEC.2019.008.026

\author{
BENJAMIN SELEKE \\ North-West University, South Africa
}

MARIETJIE HAVENGA

North-West University, South Africa

JOSEF DE BEER

North-West University, South Africa

\title{
THE ENHANCEMENT OF SELF-DIRECTED LEARNING THROUGH THE ENGAGEMENT IN PROBLEM-BASED LEARNING ACTIVITIES DURING A PROFESSIONAL DEVELOPMENT PROGRAMME ON INDIGENOUS KNOWLEDGE FOR TECHNOLOGY TEACHERS
}

\begin{abstract}
:
The aim of this qualitative case study was to explore the affordances of a short learning programme to sensitize Technology teachers towards self-directed learning regarding the infusion of indigenous knowledge in the curriculum. The short learning programme on indigenous knowledge was structured according to the steps of problem-based learning. Technology teachers participated in this short learning programme as part of their continuous professional development. Among others, the national curriculum accentuates active learning as well as the appreciation of indigenous knowledge as a valued resource of history and culture. It is essential that Technology teachers are supported to acquire indigenous knowledge themselves and enable them to effectively guide learners in this regard. Accordingly, a short learning programme was developed and implemented for the purpose of the training of Technology teachers. Qualitative data was collected through reflective sheets, a focus group interview, as well as photographic artefacts, in order to generate an integrated qualitative dataset. During meticulous thematic qualitative data analysis, using protocol coding (a priori coding) data was organised and grouped into related themes. The emerging themes not only provided evidence for the acquisition of problem-based learning skills, but also revealed the inherent ability of problem-based learning related to indigenous knowledge, to enhance self-directed learning abilities among Technology teachers.
\end{abstract}

\section{Keywords:}

indigenous knowledge, problem-based learning, professional development, self-directed learning, technology teachers

JEL Classification: 123, 124 


\section{Introduction and literature review}

The national school curriculum in South Africa, the Curriculum and Assessment Policy Statement for Senior Phase Technology (Department of Basic Education, 2011), is based on principles such as social transformation, gaining high knowledge and skills through inclusivity and active learning, and recognises the potential value contribution of indigenous knowledge systems to attain the learning outcomes of the Technology curriculum. Hence, it is essential that teachers adhere to the policy requirement by infusing their curriculum with cultural perspectives, knowledge and skills to contribute to the conservation of indigenous richness in their communities. Existing research in South Africa focuses mainly on the implementation and use of indigenous knowledge for Mathematics, Life Sciences, and Natural Sciences curricula (Havenga, 2019). The infusion of indigenous knowledge in the Technology curriculum in the South African context has largely being neglected in existing literature. In an attempt to address this knowledge gap, a short learning programme (SLP) on indigenous knowledge was developed by a higher education institution in South Africa for the continuous professional development of Technology teachers. Consequently, the aim of this research was to explore how a short learning programme can provide opportunities for Technology teachers to obtain indigenous knowledge and skills.

\section{$1.1 \quad$ Indigenous Knowledge}

Emeagwali (2014:1) asserts that "Indigenous Knowledge (IK) may be defined as the cumulative body of strategies, practices, techniques, tools, intellectual resources, explanations, beliefs, and values accumulated over time in a particular locality, without the interference and impositions of external hegemonic forces". Gandile, Tessema and Nake (2017) state that IK comprises local knowledge, traditional knowledge, health knowledge and indigenous technical knowledge among others. As a diverse nation, South Africa has rich indigenous knowledge, practices and traditions which inform how each community solve particular problems. We emphasise the 'locus of indigenous knowledge' as inherently situated in genealogy as a cultural repository where such knowledge is connected, transferred and extended from one generation to the next.

\subsection{Indigenous Technology}

There is a strong emphasis to include indigenous knowledge in the Technology education curriculum in South-African schools. Technology allows for the development of innovation and critical thinking as learners have to make decisions, solve real-world problems and apply appropriate practical skills. According to the policy document (CAPS, 2011), the technological design process comprises skills such as investigation, design, making, evaluation and communication. Knowledge of structures and materials are also essential. Moreover, the curriculum requires from learners to understand and apply technological knowledge and cultivate various views on technology in society (CAPS, 2011). Indigenous technological knowledge denotes a distinctive form of local knowledge since it involves actions and processes, and includes the development of technological artefacts as encapsulated in societies, culture and heritage (Havenga, 2019). Gumbo (2015:61) claims that technology is "inherently cultural" as the design and development of artefacts reflect cultural beliefs. He elaborates on an integrated view (western and indigenous) of Technology Education, comprising five main issues (Gumbo, 2015:70): 
- Development of a learner with an "open-mind" who can responsibly apply relevant technologies in a particular local context;

- Technological content knowledge should embrace values, designs, materials and applications with the aim to enrich people's lives;

- Learning support materials need to include the incorporation of textbooks, relevant resources, and "techno-labs" for the understanding and manufacturing of artefacts that are related to both the western and indigenous technological worlds;

- Pedagogical approaches should be "invitational" to all leaners, where they actively engage with community members and the elders regarding the design and development of products;

- Assessment should be "context sensitive" and assist learners to be skillful and professional in their field of study.

Likewise, Gumbo (2015:70) highlights the challenges of teachers in indigenous technology as follow: they need to accommodate all learners, regardless of their cultural contexts, as learners enrich teaching and learning activities with cultural nuances. Furthermore, "indigenous teachers" should mentor their peers, and they need to interact with the community to gain wisdom from the elders. Teachers and learners should also engage in technological activities, and take into account the cultural context and develop practical solutions to certain problems. Accordingly, we developed an SLP for Technology teachers at our higher education institution in South Africa, in order to explore the infusion of indigenous knowledge in Technology according to the steps of problem-based learning (PBL).

\subsection{The implementation of a short learning programme in a problem-based context}

An SLP was developed to provide opportunities for acquiring indigenous knowledge, skills and practices where Technology teachers collaborated to address a real-world problem and share their experiences. An SLP provides opportunities for elaborating on knowledge and skills in a particular field of study over a limited period of time. Worldwide, teachers work in diverse communities that require the inclusion of teaching pedagogies to accommodate indigenously diverse learners in the classroom (Gumbo, 2016). Problem-based contexts provide for subjectspecific dialogue, innovation and synergistic development of solutions to a problem.

PBL is a pedagogical strategy and driver of learner-centered activities where learners identify specific needs, formalise goals, do relevant research and develop solutions to a problem (Krajcik \& Shin, 2014; Havenga, 2015). Hence, problem-based activities start with a driving question or challenge to be addressed. Problem- and project-based learning includes aspects of the other (Swart \& Havenga, 2019) and allow for team collaboration, critical argumentation and decision making to address a problem in the best interest of the team. As a result, members develop essential skills for future demands as they learn from past and present experiences. Although PBL is a learner-centered approach, teachers are involved in the detailed planning, facilitation and direction of activities that learners need to apply in a problem context. It is imperative that the teacher selects an appropriate ill-defined problem or challenge, assists learners and requires regular feedback (Havenga, 2015). Savery (2015) emphasises an analysis of what has been 
learned from addressing and solving the problem. A closing discussion should follow on "... what concepts and principles have been learned" (Savery, 2015:9). Furthermore, it is essential that indigenous teachers should discuss the impact of development with the learners.

Savery (2016:8) also highlights the development of self-directed learning when employing PBL as strategy. As PBL is a learner-centered approach, learners should engage with the problem and develop responsibility for their own learning. According to Knowles (1975), the process of selfdirected learning consists of individuals who take initiative for their learning activities, diagnose their learning needs and formulate learning goals, identify relevant resources for learning, select suitable learning strategies, and evaluate learning outcomes.

In the current research, teachers worked together in an SLP to solve the following problem and developed indigenous technological artefacts as outlined in the given scenario: "people in a local community have to cross a river to get to banks, shops, and medical facilities in the town. Children also need to cross the bridge to go to school and the elderly need to collect their government grants in town. At times this can be dangerous, especially when the water level rises after rains. The closest bridge is far away. Crocodiles have also been spotted in the area. As a result, a bridge should be developed for the community. It must be long enough to allow someone to cross the river safely without needing to walk on the riverbanks. Technology teachers are requested, as part of an SLP in indigenous technology, to develop a bridge artefact using dowel sticks, rope, and glue" (Havenga, 2019).

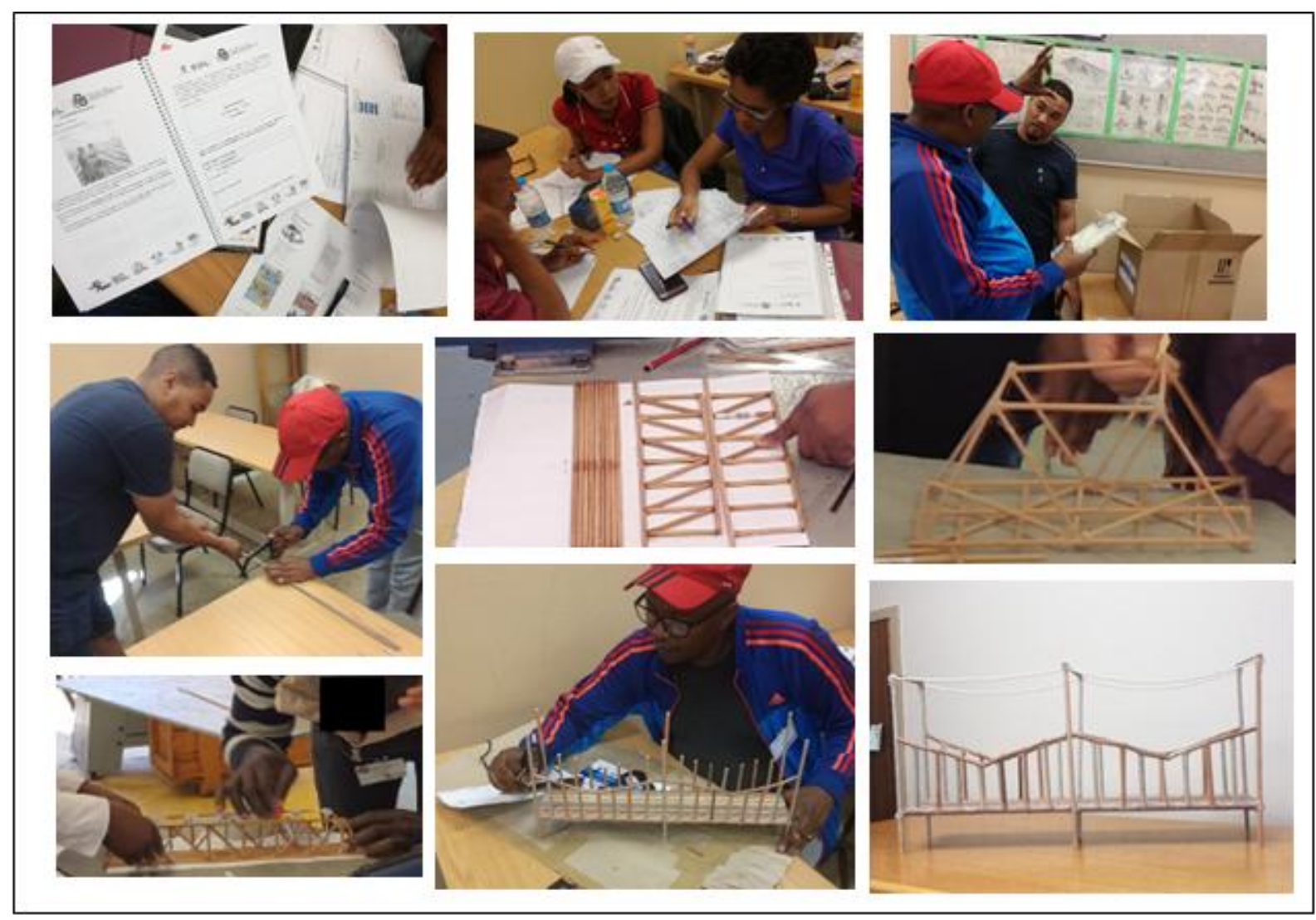

Figure 1: Photographic evidence displaying the application of problem-based learning skills during various steps of the design process and construction of a bridge artefact 
Teachers should have a vision of acquiring indigenous knowledge themselves and applying it in practical tasks. The number of teachers working together on an SLP is ideally in groups of two to three. The advantage is that each of the team members has to take responsibility for tasks and work together to give meaning and bring capacity to the team. Attendance of the SLP allowed teachers the opportunity for professional development by turning relevant knowledge that they gained, into practical skills by designing and constructing a bridge artefact. Figure 1 provides qualitative photographic evidence displaying participants' application of problem-based learning skills during various steps of the design process and construction of a bridge artefact. Creating such a tangible indigenous artefact together may result in "developing a cultural awareness and creating stewards of cultural resources" for indigenous contexts. Since the purpose of this qualitative case study was to explore the infusion of indigenous knowledge according to the steps of problem-based learning among Technology teachers, the research question was as follows: How can a short learning programme provide opportunities for Technology teachers to obtain indigenous knowledge and skills?

\section{Research design and methodology}

For the purpose of this study, which is anchored within the social constructivist approach, a qualitative case study research design was followed, and data was generated through qualitative methods, i.e. teacher reflective sheets, a focus group interview, and photographic artefacts. In this design-based research (DBR) the short learning programmes were conceptualised according to the insights of Vygotsky (1978), who saw learning occuring on two levels or planes. On the first plane, teachers socially construct learning, by engaging in problem- and project-based learning. On the second plane, teachers internalise this knowledge during reflective activities. In true DBR fashion, the short learning programme evolved over several cycles of implementation. After each cycle, design principles were distilled, to inform the next cycle. Table 1 reports the general demographical profile of the Technology teachers who participated in this qualitative investigation.

Table 1: Demographical profile of participating Technology teachers

\begin{tabular}{|l|c|c|c|c|c|}
\cline { 2 - 5 } \multicolumn{1}{c|}{} & Teacher 1 & Teacher 2 & Teacher 3 & Teacher 4 & Teacher 5 \\
\hline Gender & Female & Male & Male & Female & Male \\
\hline Cultural-language group & $\begin{array}{c}\text { Coloured } \\
\text { Afrikaans }\end{array}$ & $\begin{array}{c}\text { Coloured } \\
\text { Afrikaans }\end{array}$ & Setswana & $\begin{array}{c}\text { Coloured } \\
\text { Afrikaans }\end{array}$ & Setswana \\
\hline $\begin{array}{l}\text { Total number of years } \\
\text { teaching experience }\end{array}$ & $\begin{array}{c}\text { Not } \\
\text { indicated }\end{array}$ & 3 & 2 & Not & Not \\
indicated \\
\hline $\begin{array}{l}\text { Participated in the focus- } \\
\text { group interview }\end{array}$ & Yes & Yes & Yes & No & No \\
\hline
\end{tabular}

Five teachers, attended a three day SLP during which indigenous knowledge was implemented and used for teachers' continuous professional development with regard to the core content areas in the Senior Phase Technology curriculum. As part of the SLP learning outcomes, the participants were guided to apply their design process skills to develop a bridge artefact for a village, while following the steps of PBL as proposed by Havenga (2019). Informed consent was 
obtained from all participants, and ethical approval granted from our HEls Research Ethics Committee, prior to the commencement of the research. Participants were requested to each complete a teacher self-reflective sheet, followed by a focus group interview with three of the five participants, in order to further enrich, verify and clarify the existing data obtained from the reflective sheets. Photographic artefacts were also collected during the SLP to provide visual evidence for our findings. Participants granted us formal permission and consent to take digital photographs of them during the SLP, and also to make use and publish these artefacts as part of our reporting of findings. The integrated qualitative dataset was thematically analysed according to the PBL steps, using protocol coding (a priori coding), since this type of coding is done according to "pre-established" activities following "the source's specific procedures" (Saldaña, 2016:175, 176).

\section{Discussion of findings}

Table 2 reports on the findings derived from our qualitative thematic data analysis pertaining to the acquisition of PBL. Participant responses, reflected by verbatim quotations, provide evidence for the attainment of all steps of PBL applied throughout the design process.

Table 2: Qualitative findings related to teachers' application of the steps of PBL in the design process, while acquiring indigenous knowledge and skills

\begin{tabular}{|c|c|c|}
\hline PBL Steps & $\begin{array}{l}\text { Evidence that Teachers applied PBL } \\
\text { Steps in the Design Process during the } \\
\text { SLP on Indigenous Knowledge }\end{array}$ & $\begin{array}{l}\text { Evidence for the Acquisition of } \\
\text { Indigenous Knowledge and Skills }\end{array}$ \\
\hline Conceptualise & $\begin{array}{l}\text { "Technology ... has an interrelationship } \\
\text { between community, environment" } \\
\text { (Teacher } 1(\mathrm{~T} 1) \text { ). "The infusion of } \\
\text { humanity and culture in teaching and } \\
\text { learning of technology it's so mind- } \\
\text { blowing" (T3). }\end{array}$ & $\begin{array}{l}\text { "Increased interest of drawing upon the } \\
\text { indigenous knowledge ... by the help of } \\
\text { our lecturer it makes it easier ... to get } \\
\text { with the course" (T5). "Conceptualisation } \\
\text { simulates creativity and critical thinking } \\
\text { skills" (T3). }\end{array}$ \\
\hline $\begin{array}{l}\text { Discuss the } \\
\text { problem } \\
\text { context }\end{array}$ & $\begin{array}{l}\text { "Village people ... want to cross the river } \\
\ldots \text { people need a bridge" (T1). }\end{array}$ & $\begin{array}{l}\text { "Determine resources to solve the } \\
\text { problem" (T3). "We engage in problem- } \\
\text { solving by using cooperative learning } \\
\text { skills" (T5). }\end{array}$ \\
\hline $\begin{array}{l}\text { Identify } \\
\text { knowledge } \\
\text { and needs }\end{array}$ & $\begin{array}{l}\text { “... the bridge must be strong, stable, wide } \\
\text { enough, safe, kind of mechanism to easily } \\
\text { get access to stairs, ramp ... must be } \\
\text { environmental friendly, non-slippery } \\
\text { wooden surface" (T1). "... safety, } \\
\text { environmentally friendly, cost, durability" } \\
\text { (T2). "The materials ... to build the bridge } \\
\text { should not harm the environment and it } \\
\text { should be cost effective" (T4). }\end{array}$ & $\begin{array}{l}\text { "Solution must be based on knowledge } \\
\text { and how to apply it" (T2). "IK and } \\
\text { sophisticated knowledge were used to } \\
\text { meet our needs ... we engaged the } \\
\text { elderly people to share with us ... } \\
\text { methods and knowledge" (T5). }\end{array}$ \\
\hline $\begin{array}{l}\text { Formulate } \\
\text { learning } \\
\text { objectives }\end{array}$ & $\begin{array}{l}\text { "Formulate learning objectives directly } \\
\text { linked to the problem" (T3). "... interact } \\
\text { constructively and promote group work" } \\
\text { (T2). "The design should be constantly } \\
\text { tested for the purpose intended" (T2). "If } \\
\text { the ideas not meet the requirements we } \\
\text { must adapt it until they do" (T1). }\end{array}$ & $\begin{array}{l}\text { "The SLP ... helped us to recognise how } \\
\text { we can formulate our learning } \\
\text { objectives" (T5). }\end{array}$ \\
\hline
\end{tabular}




\begin{tabular}{|c|c|c|}
\hline Investigate & $\begin{array}{l}\text { "Acquire appropriate resources ... making } \\
\text { informed decisions" (T3). "We also use } \\
\text { knowledge of the elderly people to } \\
\text { investigate" (T5). }\end{array}$ & $\begin{array}{l}\text { "Investigate what materials and } \\
\text { machinery will be needed to build the } \\
\text { bridge" (T5). "If the bridge ideas does not } \\
\text { serve the purpose it should be re- } \\
\text { evaluated" (T4). }\end{array}$ \\
\hline $\begin{array}{l}\text { Design and } \\
\text { develop }\end{array}$ & $\begin{array}{l}\text { "... draw a few ideas to solve the problem } \\
\text { and choose the best one... changes were } \\
\text { made and one needs to go back to the } \\
\text { drawing board" (T1). "Our task was to } \\
\text { design a bridge [prototype] make up out of } \\
\text { recycled material" (T1). "Evaluate each } \\
\text { [idea] in terms of advantages and } \\
\text { disadvantages" (T3). }\end{array}$ & $\begin{array}{l}\text { "... saver working practices, skills are } \\
\text { increasing, better organising... suitability } \\
\text { and purpose of the material, the impact } \\
\ldots \text { towards the environment" (T1). "All } \\
\text { group members know from start what } \\
\text { their role will be ... complete their part to } \\
\text { the best of their ability" (T1). "... will be } \\
\text { able to critically reflect" (T3). "learning } \\
\text { activities ... linking prior knowledge to } \\
\text { new knowledge [IK]" (T5). }\end{array}$ \\
\hline Assess & $\begin{array}{l}\text { "... group member also see the value that } \\
\text { he/she has contributed in solving the } \\
\text { problem successfully" (T1). "Our group } \\
\text { members were full of energy on compiling } \\
\text { the information and building the bridge ... } \\
\text { solving people's problem by building a } \\
\text { strong and steady bridge" (T5). }\end{array}$ & $\begin{array}{l}\text { "... every member of the group shared } \\
\text { accountability and responsibility" (T2). } \\
\text { "Give group members specific tasks. } \\
\text { This will ease the task on each member } \\
\ldots \text { and the group will meet their } \\
\text { deadlines. Communication in this regard } \\
\text { is vital" (T4). "... cooperative skills were } \\
\text { attained" (T5). }\end{array}$ \\
\hline
\end{tabular}

The research aim was to determine how an SLP can provide opportunities for Technology teachers to obtain indigenous knowledge and skills. The findings indicated various exemplars where Technology teachers applied PBL steps as part of an SLP to obtain indigenous knowledge and skills (Table 2). Teachers conceptualised the construct of indigenous knowledge and T3 mentioned "The infusion of humanity and culture in teaching and learning of technology it's so mind-blowing". Participants discussed the problem contexts and outlined the knowledge and needs required. Building a bridge should include a mechanism to easily get access for example using stairs or a ramp, it should be environmental friendly, using a non-slippery wooden surface (T1) and it should be cost effective (T4). Learning objectives involved that participants need to interact constructively and collaborate in designing and developing the bridge. The bridge artefact should also be tested for strength. Participants used various resources and also emphasised knowledge of the elderly in the village (T5).

Participants designed and developed a bridge prototype using environmental friendly and recycled materials. During assessment, team members determined individual as well as group contribution to solve the problem. T5 noted that "Our group members were full of energy on compiling the information and building the bridge ... we achieved in solving people's problem by building a strong and steady bridge". Participants developed numerous skills during the SLP. For example the ability to develop interest in indigenous knowledge (T5), enhance critical thinking (T3), identify knowledge and emphasise experiences of the elderly (T5), formulate learning objectives (T5) and investigate various resources (T5). Technology teachers obtained particular skills during design and development of the artefact, such as group management and identification of members' roles (T1), critical reflection (T3) and elaboration on their learning (T5). Moreover, participants shared accountability and responsibility (T2), met deadlines, 
communicated effectively (T4) and effectively cooperated (T5). As a result, attending the SLP provided for teachers with more nuanced understandings of indigenous knowledge systems, and an array of skills to solve an indigenous real-world problem. In addition, Table 3 shows numerous examples of core SDL abilities that Technology teachers developed during the SLP.

\section{Table 3: Qualitative findings from the focus-group interview related to the development of SDL abilities among Technology teacher participants}

\begin{tabular}{|c|c|}
\hline $\begin{array}{l}\text { Core SDL abilities } \\
\text { (Knowles, 1975:18) }\end{array}$ & $\begin{array}{l}\text { Evidence for the development (or at least awareness) of SDL abilities } \\
\text { among Technology teachers }\end{array}$ \\
\hline $\begin{array}{l}\text { Taking initiative, with } \\
\text { or without the help of } \\
\text { others }\end{array}$ & $\begin{array}{l}\text { "....it is very important that we stay in contact with upskilling ourselves" (T1). } \\
\text { "...but at the end of the day it is upon you as an individual, you require this in } \\
\text { order to upskill yourself, as the teacher it is a calling, we do it for the love of } \\
\text { teaching and we take it to the learners where they can use as self- } \\
\text { employment" (T1). }\end{array}$ \\
\hline $\begin{array}{l}\text { Diagnosing learning } \\
\text { needs }\end{array}$ & $\begin{array}{l}\text { "... technology is not only about the doing and drawing part ... I am not that } \\
\text { good with the drawing part of technology, because we need to draw the } \\
\text { bridge first on paper and build them, so I am lacking with the drawing part" } \\
\text { (T1). }\end{array}$ \\
\hline $\begin{array}{l}\text { Formulating learning } \\
\text { goals }\end{array}$ & $\begin{array}{l}\text { "... if you set yourself goals you need to have step by step process you will } \\
\text { follow, if you see that you have missed something ... you can go back to the } \\
\text { drawing board and try to see how can you plan around whatever that is } \\
\text { hindering you from attaining your goals" (T2). "... I want to attain certain goals } \\
\text { and how I am going to do it" (T3). }\end{array}$ \\
\hline $\begin{array}{l}\text { Identifying human } \\
\text { and material } \\
\text { resources for } \\
\text { learning }\end{array}$ & $\begin{array}{l}\text { “... find resources to finish this project of the bridge, so it made me more } \\
\text { wiser ... and also how you planning to get assistance or knowledge that you } \\
\text { require, you need assistance from the HOD's and the school, I do believe that } \\
\text { there are many ways of getting necessary help that you require when you use } \\
\text { that tool" (T2). }\end{array}$ \\
\hline $\begin{array}{l}\text { Choosing and } \\
\text { implementing } \\
\text { appropriate learning } \\
\text { strategies }\end{array}$ & $\begin{array}{l}\text { "... find association or organisations that deals with technology to liaise with } \\
\text { them. Attend conferences so that we get to learn. If there are any } \\
\text { technological roadshows you will then attend, you can also research. } \\
\text { Constantly upskill yourself, on the radio they talked about this device ... the } \\
\text { parts of cars do have sensors so this device will be able to sense the problem } \\
\text { and automatically communicate with you. When you are able to keep up with } \\
\text { such trends, the quest to get to do more or to know more, how do you then } \\
\text { sharpen your skills" (T3). }\end{array}$ \\
\hline $\begin{array}{l}\text { Evaluating learning } \\
\text { outcomes }\end{array}$ & $\begin{array}{l}\text { "... it gave me an insight as to what is expected from the learners as we have } \\
\text { been doing it now as educators ... when I go back to my learners I can } \\
\text { explain what is expected from them, where they need to go to find resources } \\
\text { to finish this project of the bridge, so it made me more wiser" (T2). }\end{array}$ \\
\hline
\end{tabular}

Data obtained from the focus-group interview was thematically analysed according to these SDL abilities (Table 3), as identified by Knowles (1975). The findings that emerged from our qualitative data analysis from the focus-group interview clearly provide evidence (Table 3 ) that the SLP provided teachers with more nuanced understandings of SDL, and assisted them in developing skills necessary for SDL. 


\section{Conclusions and recommendations for future research}

This research indicated that an SLP provided valuable opportunities for Technology teachers to further develop their knowledge and skills concerning indigenous knowledge and enabled them to implement IK by developing a bridge of recycled materials. PBL was applied as pedagogical strategy, participants were inspired and acquired numerous skills involved in indigenous knowledge. A limitation of this study is that only a small number of Technology teachers participated. A larger group of teachers will provide rich data with a variety of experiences.

It is recommended that future research should be conducted to verify the inherent ability reported in the current investigation of infusing indigenous knowledge into technology education, guided by the steps of PBL proposed by Havenga (2019), to enhance SDL abilities among Technology teachers. Such studies could use multiple methods of inquiry, among others, the self-rating instrument to measure self-directed learning developed by Cheng, Kuo, Lin and Lee-Hsieh (2010). The Cheng instrument will help to analyse Technology teachers' views on self-directed learning. This could be done by measuring the teachers' learning motivation, planning and implementation, self-monitoring, and interpersonal communication (Cheng et al., 2010:1152). Such future research initiatives should furthermore investigate, through rigorous empirical statistical analyses techniques, the interrelated dynamics that seems to exist between constructs of indigenous knowledge systems, the steps of PBL, and SDL abilities.

\section{Acknowledgements}

This project was funded by the NRF and Fuchs Foundation.

\section{References}

Cheng, S., Kuo, C., Lin, K., \& Lee-Hsieh, J. 2010. Development and preliminary testing of a self-rating instrument to measure self-directed learning ability of nursing students. International Journal of Nursing Studies, 47:1152-1158.

Department of Basic Education (DBE). 2011. Curriculum and Assessment Policy Statement (CAPS). Grades 10-12. Mechanical Technology. Pretoria: Government Printing Works.

Emeagwali, G. 2014. Intersections between Africa's Indigenous Knowledge Systems and History. In G. Emeagwali \& G. J. S. Dei (Eds.), African Indigenous Knowledge and the Disciplines (Vol. 2, pp. 117). AW Rotterdam, The Netherlands: Sense Publishers.

Gandile, A.U., Tessema, S.M. \& Nake, F.M. 2017. Biodiversity conservation using the indigenous knowledge system: The priority agenda in the case of Zeyse, Zergula and Ganta communities in Gamo Gofa Zone (Southern Ethiopia). International Journal of Biodiversity and Conservation, 9(6):167-182.

Gumbo, M.T. 2015. Indigenous Technology in Technology Education Curricula and Teaching. In P.J. Williams, A. Jones, \& C. Buntting (Eds.), Contemporary issues in technology education: The future of technology education. (pp. 57-75). Singapore:Springer. 
Gumbo, M.T. 2016. Pedagogical Principles in Technology Education: An Indigenous Perspective. In G. Emeagwali \& E. Shizha (Eds.), African Indigenous Knowledge and the Sciences (Vol. 4, pp. 12-32). Rotterdam, The Netherlands: Sense Publishers.

Havenga, H.M. 2015. Project-based learning in higher education: Exploring programming students' development towards self-directedness. South African Journal of Higher Education, 29(4):135-157.

Havenga, M. 2019. Engaging in indigenous technology: conceptualisation and contextualisation in problembased environments. In J. De Beer (Ed.). The decolonization of the curriculum project: The affordances of indigenous knowledge for Self-Directed Learning. AOSIS book (in press).

Knowles, M. 1975. Self-directed learning: A guide for learners and teachers. Chicago, IL: Follett.

Krajcik, J.S. \& Shin, N. 2014. Project-based learning. In R.K. Sawyer (Ed.), The Cambridge Handbook of the Learning Sciences. Cambridge Handbooks in Psychology. (pp. 275-297). Cambridge: Cambridge University Press.

Saldaña, J. 2016. The coding manual for qualitative rsearchers. London: Sage.

Savery, J.R. 2015. Overview of problem-based learning: definitions and distinctions. In A. Walker, H. Leary \& C. Hmelo-Silver (Eds). Essential Readings in Problem-Based Learning: Exploring and Extending the Legacy of Howard S. Barrows. West Lafayette: Purdue University Press.

Swart, A.J. \& Havenga, M. 2019. Correlating learning outcomes to the graduate attributes of the International Engineering Alliance in a problem-based learning module. IEEE Global Engineering Education Conference (EDUCON), Dubai, UAE (9-11 April). 41-45.

Vygotsky, L.S. 1978. Mind in society. Harvard University Press. 